\title{
Teaching Current Events in Secondary Level Social Studies Classroom in Nepal
}

\author{
Keshav Raj Dhakal \\ dhakalkeshav@hotmail.com \\ Reader \\ Central Department of Education, T.U., Kirtipur
}

\begin{abstract}
The purpose of the study was to explore how social studies teachers follow the current events in social studies classroom. The study used phenomenological approach of qualitative research design. In this study, semi structured interview technique was used as qualitative research method was utilized as a means of data collection. For this purpose, interviews were held with 10 social studies teachers in the study group. The interview were recorded on an audio recorder to avoid data loss and then after transcribed. The primary mode of analysis is the development of categories or themes from the raw data. The themes were divided into eight groups and analysis was made through the interpretative method. The results showed that all social studies teachers followed current events in their classroom. It has become necessary to prompt the more active participation of students in the classroom to take advantage of current events to make the social studies lesson more interesting and fun.
\end{abstract}

Keywords: Social studies, current events, phenomenological approach, qualitative interview, secondary school

\section{Introduction}

Social studies forms that part of the school curriculum which includes subject matter and activities that enable the students to acquire an understanding of human relationships, a knowledge of the environment, principles and values of society and commitment to participate in the process of changing society. The social study program includes those aspects of human relationship and social values, and changes believed to be of greatest importance for the education of the students. It is the integrated study of the social sciences and human relationship, studies of society and social values. Social studies usually refer to that portion of the social sciences used by the school for instructional purposes (Estvan, 1968). Social studies are based on the social sciences. Social studies program is the study of man and his interaction with his social and physical environment in the past, present and emerging future. (Michaelis, 1976).It is not individual subject, discipline or sciences. The concepts of social studies start from home region or community and extend up to the international level. Social studies prove quite helpful in the development and progress of both the individual and society. 
Soon after the second world war, people began to realize especially, in the united states of America, that the understanding of man and his problems in society required a lot more than what was covered by the social sciences, hence social studies was introduced in the schools. Social studies is a subject which is taught as a compulsory subject in school education. The ministry of education, science and technology has proposed social studies as a compulsory subject in the school level education in Nepal. At the primary school level, social studies and creative arts have been included it generally focuses on the family and local community, by lower secondary level further added emphasis on population education and secondary school, the social studies curriculum becomes more discipline based and content specific. The National Council for the Social Studies (NCSS, 1994) has defined the primary purpose of social studies education as "helping young people make informed and reasoned decisions for the public good as citizens of a culturally diverse, democratic society in an interdependent world.

Social studies has long advocated the use of current events as important for teaching democratic values and participation with some advocates suggesting that the curriculum and unit studies be centered around the examination of controversial and current events (Hunt \& Metcalf, 1955; Oliver \& Shaver, 1966; Engle \& Ochoa, 1988). Today's social studies for all grade levels describe multiple ways to approach the teaching of current events and identify skills students need for obtaining and interpreting information about current events (Dynnessonand Gross, 1999; Martorella, 1996; Laughlinand Hartoonian, 1995; Sunal and Haas, 1993)). The use of current events in social studies classes serves to create and develop students' social consciousness and helps to increase students' global awareness and contributes to the enrichment of learning experiences and an awareness of social situations and problems that students may encounter in daily life and offers students the ability to consider how to solve social problems.Tying curriculum to current events helps students recognize the immediate value of their studies. Teaching current events prepares students to become more informed citizens. Current events can bring about many strong opinions and emotions to the students. This is because current events not only expand the scope of the objectives and achievements for social studies courses, but they also support students' learning and social lives.

The social studies teacher should select reliable news source and avoid ones that are not reliable. The teacher's task in this process is to bring reliable current events into the classroom and encourage students to analyze, evaluate and draw conclusions from these examples.Hunt and Metcalf (1955) described the current events movement as having the ability to introduce fresh content into the curriculum, but warned that there might be a tendency to focus on the trivial or emphasize reporting of news rather than the more difficult analysis and interpretation needed to link current events to the curriculum.

Teachers can transfer reallife examples from everyday life into their classrooms. In this respect, to achieve these educational objectives, it is necessary to integrate in-school and out-of-school experiences into the teaching process, transferring current and scientific events from everyday life to the classroom environment, thus helping students develop logical conclusions through learning about these events (Deveci, 2007).Students can achieve significant learning outcomes if certain problems in daily life are discussed in the social studies classroom.Current events provide 
Teaching Current Events in Secondary Level Social Studies Classroom in Nepal / 91

the social studies student an opportunity to link social studies content to real life problems, thereby making the curriculum more relevant (Logan, 2011). The practice of using current events seems to fit naturally with the social studies curriculum, but there is very limited research on the using current events in the social studies in school education.

\section{Research Questions/objectives}

My main research question of this study was: What are the experiences and preferred strategies of, secondary level social studies teachers who include current events in their classrooms? Major sub questions included in this study were: What strategies teachers use to incorporate current events into their classrooms? What challenges are faced by teachers who incorporate current events in their classrooms? What skills that teachers aim to develop in their students through teaching current events?

This study mainly aimed to determine the extent to which social studies teachers included current events in their teaching in class room, their sources of information about current events, the methods and techniques they used while teaching current events in social studies class and the skills and values the teacher wanted to develop to their students.

\section{Methods of the study}

A phenomenological study design was used as a research design that aims to investigate information about facts and experiences using a realistic and inductive method. The purpose of phenomenological research is to generate clear, systematic and precise descriptions of the meaning of experience (Polkinghorne, 1983). In this study,phenomenological study explores what social studies teachers lived experienced and focuses on their experience of teaching current events in social studies classroom. In order to understand the central phenomenon of the research, a purposive sampling was used for finding participants. Patton (1990) informed that there are no rules of sample size in qualitative research. However, Leedy and Ormrod (2010) suggested that the number of sample size in phenomenological research should range from five to twenty five. In this study, there were only ten secondary social studies teacher as participants selected through a purposive sampling in Bhaktapur district.

The qualitative interviewing method was used in order to determine the participant's views on the practices used in the teaching of current event in teaching social studies. The purpose of qualitative interviews is to understand things that are not directly observable, such as participants' feelings, thoughts, ideas and behaviors (Patton, 2002). Essential data were acquired through the interviews. The interview were recorded on an audio recorder to avoid data loss and then after transcribed. The primary mode of analysis is the development of categories or themes from the raw data. The themes were divided into eight groups as reasons why teachers follow current events, sources used by teachers when teaching current events, teachers' criteria for selecting current events, the techniques teachers used when teaching current events, the skills that teachers aim to develop in their students through current events, social studies content in which teachers use current events, problems that teachers encounter in using current events and opinions on the adequacy of social studies textbooks in terms of current events textbook. After collecting data, analysis of the data acquired was made through the interpretative method. 


\section{Results and Discussion}

The findings are presented in a systematic way with the objectives of this study. In this study all social studies teacher followed current events while teaching social studies in class room. Haas \&Laughlin (2000) found that $90 \%$ of social studies teachers felt a strong need to include current events in their courses. The teachers also noted that all teachers should keep up with current events. Some of the teachers provided more than one response when they used current events in their classrooms. This is because the teachers' answers to the questions were included in more than one category, thus the sum of frequency in tables exceeds than the number of participants.

\section{Reasons for the selection of current events}

Current events providelearning experiences for students at all levels.News and current events connect directly to children and young people's lived experiences and actively shape their values about the world (Moore, 2013). Using current events in social studies classrooms increases students' more sensitivity to social problems and issues. The first question to the teachers was: "Why do you follow current events in social studies class room?" When the teachers were asked about their reasons for following current events, their reasons were quite different. The categories from the respondents from interviews are presented in Table 1.

Table 1. Reasons for the selection of current events

\begin{tabular}{|l|l|}
\hline Category & $f(n=10)$ \\
\hline Awareness of local and global issues & 9 \\
\hline cover a wide range of subjects & 7 \\
\hline Developing skills such as critical thinking, problem solving and listening skills. & 5 \\
\hline Connecting with children's lived experiences & 3 \\
\hline Facilitating students' understanding & 3 \\
\hline Increment of interest in the course & 2 \\
\hline Increasing awareness & 2 \\
\hline Associating content topics & 1 \\
\hline Connecting with children's lived experiences & 1 \\
\hline
\end{tabular}

Source: Field survey, 2018

The teachers emphasized that current events should be used in the teaching and learning process. School teachers considered current events to be an essential component of social studies education. They also believed that there is a relationship between social studies and current events. The findings about the reasons for why the teachers followed current events were awareness of local and global issues, cover a wide range of subjects, developing skills such as critical thinking, problem solving and listening skills, connecting with children's lived experiences respectively. In addition, the teachers also stated that they followed current events to increase students' participation and interest in their classrooms and increasing awareness to the students. The teachers reported that they intended to develop their students' interest and awareness by taking advantage of many different current events in and out of school during their teaching. The teachers also shared that they followed current events in order to associating content topics and reinforcing learning also. 


\section{Collection sources of current events}

Newspapers, magazines and other news sources are most likely to have up-to-date information on a current event. The teachers were asked: "Which sources do you use when determining the current event to be used in the class room?" The categories obtained from this question are given in Table 2.

Table 2. Collection sources of current events

\begin{tabular}{|l|l|}
\hline Category & $f(n=10)$ \\
\hline Internet/ social sites & 9 \\
\hline Television & 9 \\
\hline Newspaper & 8 \\
\hline Radio & 6 \\
\hline Magazine & 5 \\
\hline Communication with others & 4 \\
\hline Textbook/ Reference book & 3 \\
\hline Observation & 1 \\
\hline Documentaries & 1 \\
\hline
\end{tabular}

Source: Field survey, 2018

The majority of the teachers stated that they used the web-based sources and television to follow current events and that they enriched their teaching and students' understanding by bringing these events to the classroom. In addition, the teachers also expressed that they shared current events with their students by making use of newspapers, radio, and magazines. Less frequently mentioned sources were communication with others, textbook/reference book, observations and documentaries.

\section{Criteria for selecting current events}

Current events provide authentic learning experiences for students at all grade levels (Hass \& Laughlin, 2000).Current events lead students to be proactive in coming up with solutions to the complex, connected society that they are inheriting. The third question directed to the teachers in this study was:"What kind of criteria do you consider when choosing current events in teaching your lesson?" The categories obtained from the interviews are given in Table 3.

Table 3. Criteria for selecting current events

\begin{tabular}{|l|l|}
\hline Category & $f(n=10)$ \\
\hline Relation with topics & 8 \\
\hline Interesting & 7 \\
\hline Relevance to life & 5 \\
\hline Students requirements & 4 \\
\hline Actuality of events & 3 \\
\hline Supporting to the lessons & 1 \\
\hline Importance for daily life & 1 \\
\hline
\end{tabular}

Source: Field survey, 2018

When the opinions of the teachers were examined regarding their criteria for the selection of current events, most frequently shared choices were, respectively, relation with the topic, 
interesting, relevance to life, student's requirements and actuality of the event. Other responses from the teachers were supporting to the lesson and importance for daily life.

\section{Teaching strategies of current events}

The social studies classroom in school is a place to examine current events. The teachers were also asked: "How do you bring current events into the classroom environment?" The categories are given in Table 4.

Table 4. Teaching strategies of current events

\begin{tabular}{|l|l|}
\hline Category & $f(n=10)$ \\
\hline Current events at the beginning of the class & 9 \\
\hline Current events across subject areas & 7 \\
\hline Current events one day in a week & 5 \\
\hline Current events at the end of unit & 3 \\
\hline Current events from extra-curricular activities & 2 \\
\hline Current events at bulletin and scrap board & 1 \\
\hline Current events in separate unit & 1 \\
\hline
\end{tabular}

Source: Field survey, 2018

The majority of the teacher stated that teacher taught at the beginning of the class when teaching current events. However, teachers also stated other methods. These methods were current events across subject areas, one day in a week, at the end of unit, extracurricular activities. Teachers placed less emphasis on the use of bulletin and scrap board and current events in separate unit.

\section{The skills developed in their students through teaching current events}

In studying current events students are required to use a range of cognitive, affective, research, critical thinking, and communication skills (Hass \& Laughlin, 2000). Current events are a great way to engage students in the social studies classroom. The use of current events helps students learn a variety of concepts they will encounter and will make them aware of social and cultural diversity, as well as economic facts and generalizations that exist in both their environment and the world (Degirmenci \& Ilter, 2017). The use of current events develop students' social consciousness and, helps to increase students' global awareness also. Another question directed to the teachers in this study related to what aimed to develop in their students that would help to improve their conceptual understanding. The categories obtained from the interviews are given in Table 5.

Table 5. The skills developed in their students through current events

\begin{tabular}{|l|l|}
\hline Category & $f(n=10)$ \\
\hline Social skill & 8 \\
\hline Field observation & 8 \\
\hline Social inquiry & 7 \\
\hline Problem solving & 5 \\
\hline Perception of change & 3 \\
\hline Making conclusions & 1 \\
\hline Predicting tomorrow & 1 \\
\hline
\end{tabular}

Source: Field survey, 2018 
In this study, the teachers reported that they wanted their students to develop a variety of specific skills. The social studies teachers stated different skills that, through teaching current events, they aimed to develop in their students that would help to improve their social skill. The majority of the teachers stated that they aimed to provide their students with skills of field observation and social inquiry. These skills were followed by problem solving, perception of change, making conclusion and predicting tomorrow. The results showed that teachers tried to make their students achieve skills outlined in the social studies curriculum by teaching of current events.

\section{Social studies unit in which teachers teach current events}

Research has shown that social studies teachers mostly associate current events with topics such as disasters, political problems, international problems, human rights, citizenship, science, technology and environmental problems (Bayır, 2010). In this study, the teachers were asked, "In which unit of social studies do you usually use current events in your class?" The categories obtained are given in Table 6 .

Table 6. Social studies unit in which teachers teach current events

\begin{tabular}{|l|l|}
\hline Category & $f(n=10)$ \\
\hline Development and its infrastructures & 8 \\
\hline We and our society & 8 \\
\hline Our tradition, social norms and values & 7 \\
\hline Our earth & 6 \\
\hline Civic consciousness & 4 \\
\hline Social problems and their solutions & 4 \\
\hline Our past & 3 \\
\hline Economic activities & 3 \\
\hline International relation and cooperation & 2 \\
\hline
\end{tabular}

Source: Field survey, 2018

Research has shown that social studies teachers mostly associate current events with topics such as disasters, political problems, international problems, human rights, citizenship, science, technology and environmental problems (Bayer, 2010). The social studies teachers stated that they mostly included current events in their teaching of subjects such as development and infrastructures, we and our society and our tradition, social norms and values respectively. The teachers also included our earth, civic consciousness, social problems and their solutions, our past and economic activities. The topics less emphasized by the teachers was international relation and cooperation.

\section{Challenges are faced by teachers in using current events}

Connecting current events with lessons in the classroom is difficult as it seems. When the question, "When using current events, do you face any challenges during the teaching in classroom?" The results are given in Table 7. 
Table 7. Challenges are faced by teachers in using current events

\begin{tabular}{|l|l|}
\hline Category & $f(n=10)$ \\
\hline Inadequate teaching hours & 9 \\
\hline Lack of including current events in textbook & 8 \\
\hline Lack of resources & 5 \\
\hline Students disinterest & 3 \\
\hline Students not following current events & 2 \\
\hline Classroom management & 1 \\
\hline
\end{tabular}

Source: Field survey, 2018

As seen in above Table, the majority of the teachers stated inadequate teaching hours and lack of including current events in textbook and lack of resources as the major challenges in teaching current events. In addition, the other problems mentioned less frequently by the teachers were student disinterest, students not following current events and classroom management.

\section{Opinions on the adequacy of social studies textbooks in terms of current events}

The final question posed to the teachers was: "Are social studies textbooks sufficiently adequate in their use of current events?" The findings related to the teachers' answers are given in Table 8.

Table 8. Opinions on the adequacy of social studies textbooks in terms of current events

\begin{tabular}{|l|l|}
\hline Category & $f(n=10)$ \\
\hline Adequate & 1 \\
\hline Inadequate & 9 \\
\hline
\end{tabular}

Source: Field survey, 2018

Lastly, the study's result showed that the majority of the teachers thought that social studies textbooks were not sufficient in terms of their inclusion of current events. While 9 out of 10 teachers noted that they did not think secondary level social studies textbooks sufficiently included enough current events, only one teacher stated that he found the textbooks to be adequate. The teachers stated that even outdated events that were no longer relevant were included in social studies textbooks.

\section{Conclusion}

This study examined the extent to which social studies teachers were concerned with teaching current events in the class room, the sources they used to access information about current events, the methods they used while teaching current events and the skills they wanted to develop in their students. The results showed that all social studies teachers followed current events in their classroom. This study generally helped us to examine the basic teaching beliefs and practices that teachers reported in the teaching of current events in social studies lessons. It has become necessary to prompt the more active participation of students in the classroom, to teach current events to students in a concrete way and to take advantage of current events to make the lesson fun. Teachers can also allow students to debate with their peers, allowing them to choose current events. In conclusion, all the results obtained from this study show that social studies teachers should be good advisors to their students in current event teaching and use in their classrooms. 
Teaching Current Events in Secondary Level Social Studies Classroom in Nepal / 97

\section{References}

Bayır, O.G. (2010). Current events in 4th and 5th grade primary education social studies program. Procedia Social and Behavioral Sciences. 9, 923-928.

Degirmenci, Y. \& Ilter, I. (2017). An investigation into geography teachers' use of current events in geography classes. Universal Journal of Educational Research, 5(10): 1806-1817

Deveci, H. (2007). Teachers' views on teaching current events in social studies. Educational Sciences: Theory \& Practice. 7 (1), 417-451.

Dynnesson T. L. \& Richard E. G. (1999). Designing effective instruction for secondary social studies. (Second Edition) Upper Saddle River, NJ: Merrill Prentice Hall.

Engle, S. H. \& Ochoa, A.S., (1988). Education for democratic citizenship: Decision making in the social studies. New York: Teachers College Press.

Estvan, F. J. (1968). Social Studies in a Changing World. Newyork: Brace and World.

Haas, M. E., \& Laughlin, M. A. (2000). Teaching current events: Its status in social studies today. ERIC Number: ED440899

Hunt, M. P., \& Metcalf, L. E. (1955). Teaching high school social studies: problems in reflective thinking and social understanding. New York: Harper and Brothers Publishers.

Laughlin, M. A. \& Hartoonian, H.M. (1995). Challenges of social studies instruction in Middle and High Schools: Developing Enlightened Citizens. Fort Worth: Harcourt Brace College Publishers.

Leedy, P. D., \& Ormrod, J. E. (2010). Practical research: Planning and design. Upper Sadle River, New Jersey: Merrill.

Logan, L. R., (2011). Invigorating social studies curriculum with current events. (Master's thesis, California State University Channel Island).

Michalies, J.U., (19760. Social studies for children in democracy. Englewood Cliffs, N.J.:Prentice Hall.

Moore, D. C., (2013). Bringing the World to School: Integrating News and Media Literacy in Elementary Classrooms. Journal of Media Literacy Education, 5(1) 326-336.

National Council for the Social Studies. (NCSS, 1994). Expectation of Excellence: Curriculum Standards for Social Studies. Washington, DC: Retrieved from http://www.socialstudies. org/standards/preface.

Oliver, D. W. \& Shaver J.P., (1966). Teaching public issues in the high school. Boston: Houghton Mifflin Company.

Patton, M. Q. (1990). Qualitative evaluation and research methods. Designing Qualitative

Studies. Retrieved from http://legacy.oise.utoronto.ca/research/field-centres/ross/ctl1014/ Patton1990.pdf.

Patton, M. Q. (2002). Qualitative evaluation and research method ( $3^{\text {rd }}$ edition).Newburry Park: Sage Publications. 
Polkinghorne, D. (1983). Phenomenological research methods. In Valle, R.S., \& Halling, S. (Eds). Existential phenomenological perspectives in Psychology. 41-60. Newyork: Plenum.

Martorella, P. H. (1996). Teaching social studies in Middle and Secondary Schools. Columbus, $\mathrm{OH}:$ Merrill.

Sunal C. S. \& Haas, M.E. (1993). Social Studies and the Elementary/ Middle School Students. Fort Worth: Harcourt Brace Jovanovich College Publishers. 